\title{
Prediction of Financial Health of Business Entities of Selected Sector Using Balance Analysis II. by Rudolf Doucha and Verification of Its Predictive Ability through ROC
}

\author{
Dusan Karpac ${ }^{1, *}$ and Viera Bartosova ${ }^{1}$ \\ ${ }^{1}$ University of Zilina, The Faculty of Operation and Economics of Transport and Communications, \\ Department of Economics, Zilina, Slovakia
}

\begin{abstract}
Forecasting business failure is a worldwide known term, in a global notion, and there is a lot of prediction models constructed to compute financial health of a company and, by that, state whether a company inclines to financial boom or bankruptcy. A healthy financial management of a business entity is very important for the proper operation of the business, and it is therefore very important to know how to assess financial health and to anticipate possible problems that will be easier to eliminate in advance. Globalized prediction models compute financial health of companies, but the vast majority of models predicting business failure are constructed solely for the conditions of a particular country or even just for a specific sector of a national economy. Predictive models can indicate whether an entity tends to prosper or bankruptcy, and so we can assess the financial health of the business. This paper provides a description of the balance analysis II. by Rudolf Doucha, discusses its application to a sample of 266 Slovak subjects and points to its prediction in the given field. The verification of the ability to forecast bankruptcy or financial stability has been evaluated through ROC analysis.
\end{abstract}

Keywords: Specificity, Financial prediction, ROC curve, AUC

\section{Introduction}

The term "enterprise financial health forecasting" is widely known in the world, but the intensity of how different countries are addressing this issue is uneven. Business entities in our country forecast their financial stability only in a minimalist way, mainly because the conditions for the Slovak market have so far not designed a general model of prediction that is fully applicable to any entity, regardless of the sector in which it operates. In view of this, it is necessary at least to verify which models are suitable for use in a particular sector, and that fact was the main reason for us to write this study. Since the Slovak and Czech economies are very similar to each other, we have chosen to use the balance analysis II. by Rudolf Doucha.

*Corresponding author: dusan.karpac@fpedas.uniza.sk 
Evaluation of efficiency is an integral part of rational behavior of units that aims to survive in a competitive environment in a long-term [1].

Every corporation has an economic and moral responsibility to its stockholders to perform well financially [2].

However, the number of bankruptcies in Slovakia has been growing for several years without an apparent macroeconomic cause. To prevent a rapid denigration and to prevent the outflow of foreign capital, various efforts are being zealously implemented. Robust analysis using conventional bankruptcy predictive tools has shown that existing models are adaptable to local conditions, particularly local legislation [3].

Financial hardship is the financial state of an enterprise when an enterprise has serious payment problems that cannot be resolved otherwise than by radically changing its operating or financial activity $[4,5]$.

Bankruptcy is a situation where an enterprise is unable to pay its debts and ultimately fails to meet its obligations. Bankruptcy is a condition that ends all business and economic activities, so it is also referred to as economic death [6].

Financial analysis represents a basic aspect of financial management of a business entity and points to the operation of the company. The state of financial stability of each entity is most reflected in the different forms of the profit indicator. Profit, within the result of management, represents one of the most important flow quantities. This explains how effectively corporate capital is used in the entity [7].

This study shows how the balance analysis II. indexes sample entities to bankrupt and prosperous businesses, and through the ROC analysis we verify the ability to properly redistribute these businesses.

\section{Literature review}

In order to ensure the best financial health of an enterprise, we can predict it, i.e. to predict how the funds and the total assets of an enterprise should be treated in the short or long term for their most efficient use. In order to identify the level of financial health of the company, prediction models, also called early warning systems, are used. It assesses the health of the company on the basis of complex characteristics, both in terms of past and current developments, as well as in terms of the future development of the entity [8].

Paul Joseph Fitzpatrick, in 1932, first published a study comparing the development of indicators in solvent and insolvent businesses. He pointed out that the development of selected business indicators - indicators long before the serious economic difficulties that usually result in insolvency - begin to differ in the endangered enterprises. Later, Merwin, Beaver and Altman dealt with this issue. These are considered to be the founders of forecasts and predictions of the financial health of business entities [9].

In a more recent study, the interdependence of sovereign default risk and banking fragility in Russia was investigated, using credit default swaps as a proxy for default risk.

Predictive models are constructed around the world by authors from different countries. In Slovakia, Chrastinova and Hurtosova are the most known authors [10, 11, 12]. Also in Slovakia very important author in the area of predictions is Gundova. In the neighboring Czech Republic, there are also several representatives of the area of financial crisis predictions. Absolutely best known are the spouses Inka and Ivan Neumaiers or Kislingerova. In the Czech Republic, there is also significant author, doing research and working in the prediction of bankruptcy area, Ruckova or as well Rudolf Doucha, whose model we used for evaluating in this study. 


\section{Methodology}

ROC analysis was developed as a standard methodology to quantify the ability of the signal receiver to correctly distinguish objects of interest from the background noise in the system. In the area of financial risk forecasting, ROC analyzes the correct distribution of subjects and compares two categorization algorithms, one of which is considered to be a comparative element [13].

The base reallocation we used is based on the Commercial Code and evaluates financial health under the following conditions: Equity / Liabilities $<0.04$; Current assets / short-term liabilities $<1$; Negative EAT. Business entities that met all three conditions simultaneously were included in the class of non-prosperous subjects and others were designated as prosperous businesses.

The sample of entities we have selected consists of 266 businesses in the same area. Data analysis reported 236 prosperous and 30 non-prosperous companies, and this was considered to be the standard benchmark in verifying the selected prediction model.

Balance analysis II. provides the system evaluating the company in four basic directions (stability, liquidity, activity, profitability) and subsequently one aggregate indicator. The shape the aggregate indicator of this model is as follows [14]:

$$
\text { BA II. }=(2 S+4 L+A+5 P) / 12
$$

Where:

$S=$ stability, $L=$ liquidity, $A=$ activity, $P=$ profitability

Each of these areas consist of several indicators and have their own aggregate eventual indicators as following:

$\underline{\text { Stability aggregate indicator }} \mathbf{S}=(\mathbf{2 S 1}+\mathbf{S 2}+\mathbf{S 3}+\mathbf{S 4}+\mathbf{2 S 5}) / 7$

Where:

$S 1$ = equity/fixed assets; $S 2=($ equity/total liabilities $) \cdot 2 ; S 3=$ equity/external sources; $S 4=$ total assets/(short-term debts·15); S5 = total assets/(stocks·15)

Liquidity aggregate indicator $\mathbf{L}=(5 \mathbf{L} 1+8 \mathbf{L} 2+2 \mathbf{L} 3+\mathbf{L 4}) / 16$

Where:

$L 1=(2 \cdot$ financial assets $) /$ short-term debts $;$ L2 $=(($ financial assets + receivables $) /$ short term debts) $/ 2,17 ;$ L3 $=($ current assets/short-term debts $) / 2,5 ; L 4=($ work capital/total liabilities) $\cdot 3,33$

Activity aggregate indicator $\quad \mathbf{A}=(\mathbf{A} 1+\mathbf{A} \mathbf{2}+\mathbf{A} \mathbf{3}) / \mathbf{3}$

Where:

A1 $=($ total sales $/ 2) /$ total liabilities $;$ A2 $=($ total sales $/ 4) /$ equity $;$ A3 $=($ value added $\cdot 4) /$ total sales

$\underline{\text { Profitability aggregate indicator }} \mathbf{P}=(\mathbf{3 P 1}+\mathbf{7 P 2}+\mathbf{4 P 3}+\mathbf{2 P 4}+\mathbf{P 5}) / \mathbf{1 7}$

Where:

$P 1=(10 \cdot$ EAT $) /$ value added; $P 2=(8 \cdot$ EAT)/equity; $P 3=(20 \cdot$ EAT $) /$ total liabilities; $P 4=$ $(40 \cdot$ EAT) $/$ sales; $P 5=(1,33 \cdot$ operational profit $) /$ operational profit + financial profit 
The classification of the resulting values: BAII. $>1$ symbolizes a healthy financial situation of the company; $0,5<$ BAII. $\leq 1$ neutral zone of unallocated results and if BAII. $\leq$ 0,5 unhealthy financial situation of the company. Since ROC analysis compares two sorting algorithms of subjects into two categories, we have modified the distribution of the model as follows: if BAII. > 0,75 symbolizes a healthy financial situation of the company; and if BAII. $\leq 0,75$ unhealthy financial situation of the company.

The class of enterprises, which according to the prediction model should be labeled as average, has been redistributed exactly in half, which means that we have put its middle value in the scoring interval for businesses in the gray zone, and it has been used as the threshold for determining the prosperity of entities.

\section{Results}

For the purpose of the paper we calculated the financial standing of each company through the selected prediction model. The results were compared to the definition of the company in crisis according to the Slovak legislation and by the confusion matrix of the prediction model we got the parameters evaluating the predictability of the selected model. These data are presented in the following Table 1.

Table 1. Ranking success rate ratings for Balance analysis II. by Rudolf Doucha

\begin{tabular}{|c|c|}
\hline Type I error & $0,00 \%$ \\
\hline Type II error & $20,76 \%$ \\
\hline Sensitivity & $79,24 \%$ \\
\hline Specificity & $100,00 \%$ \\
\hline Accuracy & $81,58 \%$ \\
\hline AUC & $89,60 \%$ \\
\hline
\end{tabular}

Source: Own processing.

In Table 1 we can see that error of II. type, consisting of the false denomination of 49 enterprises for non-prospering, amounts to $20,76 \%$. This is due to the fact that the 49 subjects that were mistakenly identified were in the section of 236 healthy business entities and therefore the number of incorrectly marked enterprises ultimately did not cause such a large percentage of error of second kind. The overall accuracy of the model has been reduced and evaluated to $81,58 \%$, but despite the overall accuracy of the model, the standard element evaluating its classification capability is the AUC area. 


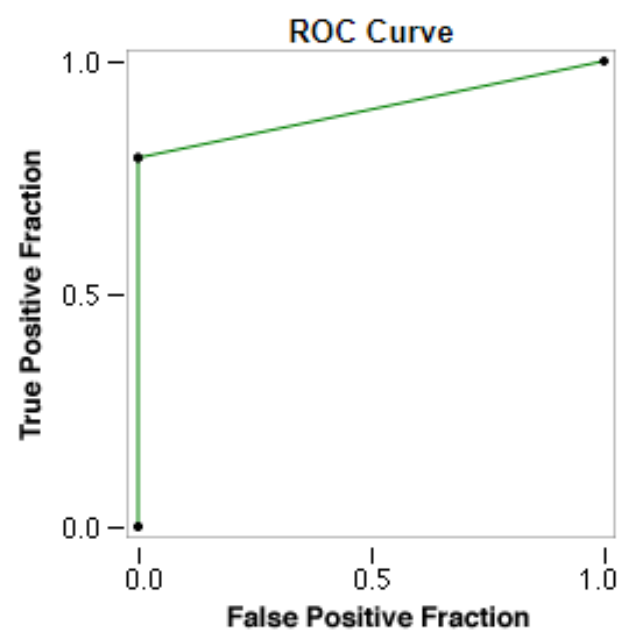

Fig. 1 Representation of the area under the ROC curve for Balance analysis II. by Rudolf Doucha Source: Own processing.

The AUC parameter reaches out $89,6 \%$ for the model application, and thus it can be demonstrated that the selected prediction model has a good classification ability if we reflect to the classification rule resulting from the theoretical knowledge obtained from Klepac and Hampel [15].

\section{Conclusion}

In all companies, the importance of enterprise evaluation keeps growing within today's ever changing economic environment. Enterprise evaluation is the basic element for understanding the sources of company competition and, at the same time, it is a source for company strategy implementation support.

Forecasting the financial health of business entities is very important. On the one hand, this is important for the businesses themselves because it makes it possible to recognize the adverse effects on development and also provides opportunities for their removal. On the other hand, it is important for investors, creditors and other entities in contact with the business that they want to know about their future development in order to protect their deposited resources.

For this contribution, 266 entities from selected sector were redistributed to bankrupt and prosperous businesses under the terms of the Commercial Code. We then processed financial analysis and enterprise prediction through Balance analysis II. by Rudolf Doucha. We compared the results of the classification of these two algorithmic methodologies and based on that comparison we worked with the first and second type error parameters, sensitivity and specificity. Subsequently, using the results of these variables, we processed the ROC curve analysis, from which the resulting AUC value under the curve, was a clear indication, and according to that, the chosen predictive model was able to clearly predict the financial health of the enterprise in the selected sector of Slovakia.

Verification analysis showed that the model has a good classification capability in the area, achieving $89,6 \%$ success 
This is paper is an outcome of project VEGA: 1/0544/19 Formation of the methodological platform to measure and assess the effectiveness and financial status of non-profit organizations in the Slovak Republic.

\section{References}

1. K. Valaskova, P. Durana, P. Adamko, J. Jaros, Financial compass for Slovak enterprises: modeling economic stability of agricultural entities. Journal of Risk and Financial Management, 13(5), 92 (2020)

2. J. Salaga, V. Bartosova, E. Kicova, Economic Value Added as a measurement tool of financial performance. Procedia Economics and Finance, 26, 484-489 (2015)

3. K. Valaskova, T. Kliestik, M. Kovacova, Management of financial risks in Slovak enterprises using regression analysis. Oeconomia Copernicana, 9(1), 105-121 (2018)

4. L. Vagner, Facility Management as a Partner of Cost Controlling at Costs Optimization in the Selected Enterprise. 17th Annual Conference on Finance and Accounting, pp. 621-629 (2017)

5. M. Durica, I. Podhorska, P. Durana, Business failure prediction using cart-based model: A case of Slovak companies. Ekonomicko-manazerske spektrum, 13(1), 51-61 (2019)

6. L. Svabova, M. Durica, Being an outlier: a company non-prosperity sign?. Equilibrium. Quarterly Journal of Economics and Economic Policy, 14(2), 359-375 (2019)

7. M. Durica, J. Frnda, L. Svabova, Decision tree based model of business failure prediction for Polish companies. Oeconomia Copernicana, 10(3), 453-469 (2019)

8. M. Kovacova, T. Kliestik, K. Valaskova, P. Durana, Z. Juhaszova, Systematic review of variables applied in bankruptcy prediction models of Visegrad group countries. Oeconomia Copernicana, 10(4), 743-772 (2019)

9. T. Kliestik, K. Valaskova, G. Lazaroiu, M. Kovacova, J. Vrbka, Remaining financially healthy and competitive: the role of financial predictors. Journal of Competitiveness, 12(1), 74 (2020)

10. P. Kral, K. Janoskova, Condition of acceptability of project risk in management of the project portfolio. 15th International Scientific Conference on Globalization and its Socio-Economic Consequences, pp. 345-352 (2015)

11. T. Kliestik, M. Misankova, K. Valaskova, L. Svabova, Bankruptcy prevention: new effort to reflect on legal and social changes. Science and Engineering Ethics, 24(2), 791-803 (2018)

12. P. Gundova,. Verifikácia vybraných predikčných metód na vzorke slovenských podnikov. Acta Academica Karviniensia. 4, 26-38 (2014)

13. T. Fawcett, An introduction to ROC analysis. Pattern Recognition Letters (2006)

14. R. Doucha, Finanční analýza podniku: praktické aplikace. Praha: VOX Consult, pp. 224 (1996)

15. V. Klepac, D. Hampel, Prediction of bankruptcy with SVM classifiers among retail business companies in EU. Universitatis Agriculturae et Silveculturae Mendelianae Brunensis, 627-634 (2016) 